\title{
Horticulture: Meeting the Needs of Special Populations
}

Diane Relf ${ }^{1}$ and Sheri Dorn ${ }^{2}$

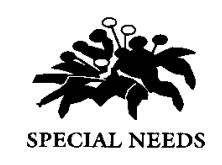

$\mathrm{M}$ eeting the needs of special populations is a role to be fulfilled by all members of the horticultural community. Understanding and addressing these needs is an integral part of conducting an extension program, running a retail nursery, hiring new horticultural employees, and performing many other aspects of horticulture today. Regardless of their areas of study, horticulture students need to be aware of the skills required and the resources available to work with special populations to be effective horticulturists in the twenty-first century.

In the past 5 to 10 years, there has been increasing research of the healing, social, and therapeutic benefits that plants impart to human life. With all of the resultant new information, people have become confused by the many facets of people-plant interactions, including the meaning of horticultural therapy. Much of this mismatching and misunderstanding has occurred at the university level, as horticulture faculty members, well-versed in crop production and basic science, have begun to try to understand and share with students the value of horticultural commodities to the consumer. Horticultural therapy frequently is used as the catch-all phrase applied to anytime anyone gardens and feels, acts, or gets better under any conditions. In some situations, it has been the term of choice to apply to children's gardening, home food production in developing countries, and hobby gardening practiced by individuals with a disability. The restorative value of views of plants and nature also have been lumped into horticultural therapy, as has the social value of community gardening. Although horticultural therapy is a very important aspect of human interaction with plants and is a rapidly growing profession, there are many other areas of people-plant interaction equally important to understanding the role of horticulture in addressing special populations.

\footnotetext{
${ }^{1}$ Extension specialist, Consumer Horticulture, Virginia Polytechnic Institute and State University, Blacksburg, VA 24061-0327.

${ }^{2}$ Graduate research assistant, Department of Horticulture, Virginia Polytechnic Institute and State University, Blacksburg, VA 240610327.

Portions of this paper are from presentations given in Japan in 1994 at Osaka and Tokyo: "Planning and conducting horticultural therapy programs for different populations, "Japan Greenery Research and Development Center Horticulture Therapy Workshop, Tokyo, Japan; and "Professional development in horticultural therapy," Heartful Park International Symposium 1994, Osaka, Japan.

The cost of publishing this paper was defrayed in pan by the payment of paper charges. Under postal regulatiows, this paper therefore must be
} hereby marked advertisement solely to indicate this fact. 
It is the purpose of this issue of HortTechnology to explore some of the different elements of people-plant interaction, such as healing, social, and therapeutic aspects, that address individuals with special needs, as well as to discuss horticultural therapy indepth and provide the reader with resources to develop teaching, research, and extension programs for these individuals.

\section{Overview}

An individual with special needs is a person who might benefit from participation in horticultural activities or from viewing plants and landscapes, but who requires special adaptations or modifications for this to occur. These special adaptations may be required because of physical, mental, or social (including economic) limitations that prohibit the individual from acting on his or her own without assistance.

Enabling or accessible gardens. Public and private gardens can be made significantly more useful to individuals with disabilities. This involves more appropriate designs and the incorporation of tools, techniques, and plant material selected to enhance gardening for the more than 55 million Americans with disabilities. The Americans with Disabilities Act mandates that public gardens become accessible to people with disabilities. Millions of individuals with dis-

abilities garden or would garden if given greater accessibility to tools and techniques that would facilitate this hobby. The fact that a person has a disability and participates in horticulture should not be taken to mean that they are involved in horticultural therapy. Having a disability does not require that all future daily life activities be considered therapy. Once persons have completed rehabilitation or therapy treatment, the term is no longer applied to their activities. Many books (see Sidebar A) (Adil, 1994; Cloet and Underhill, 1990; Please, 1990; Rothert, 1994; Yeomans, 1992) and articles (Beems, 1985; Neace, 1985; Bubel, 1990; Relf, 1994) have been pub- lished, targeted to gardeners with disabilities. With our rapidly aging population, this will be a growing area of concern. The horticulture industry is beginning to recognize the potential of this market; thus, a few relevant articles have appeared in trade publications (Fuller, 1993; Saunders, 1994).

Several arboreta and botanic gardens (see Sidebar B) have demonstration gardens that help individuals with disabilities develop home gardens. In addition, many arboreta and botanic gardens, recognizing the need to include disabled, elderly, and disadvantaged individuals in their programs and addressing the requirements of the Americans with Disabilities Act, are making buildings, grounds, and display areas accessible and expanding the scope of their existing educational programs to make them of interest and value to special populations.

The Friends of Horticultural Therapy, a support organization of the American Horticultural Therapy Association (AHTA), has as one of its areas of concern making gardening more accessible to everyone. They promote horticultural therapy by publicly advocating and providing information about making the garden more accessible to disabled individuals.

Children and school gardening. Whether or not a child has a physical or mental disability, involvement with plants has

\section{A) BOOKS Published in the United States}

Adil, Janeen R. 1994. Accessible Gardening for People with Physical Disabilities: A Guide to Methods, Took and Plants. Softcover: \$16.95. ISBN \# 0-933149-56-5.300 pages. Woodbine House, Inc. 6510 Bells Mill Road, Bethesda, MD 20817. Tel: 800-843-7323.

Francis, Mark and Randolph T. Hester, Jr., Editors. 1994. The Meaning of Gardens, Softcover \$24.95.288 pages. ISBN \# 0262-56061-5. The MIT Press, 55 Hayward Street, Cambridge, MA 02142.

Moore, Bibby. 1989. Growing with Gardening: A Twelve-Month Guide for Therapy, Recreation, and Education. 233 pages. ISBN \# 0-8078-1830-5. The University of North Carolina Press, P.O. Box 2288, Chapel Hill, NC 27515-2288

Morgan, B. 1989. Growing Together: Activities to Use in Your Horticulture and Horticulture Therapy Program: for Children. Pittsburgh Civic Garden Center, 1059 Shady Avenue, Pittsburgh, PA 15232. Tel: 412-441-4442.

Rothert, Gene. 1994. The Enabling Garden. Softcover:\$13.94. ISBN\# 0-87833-847-0. 150 pages. Taylor Publishing Company, 1550 West Mockingbird Lane, Dallas, TX 75235. Tel: 214-819-8100 FAX: 214-8198580.

Yeomans, Kathleen. 1992. The Ah/e Gardener. Soft cover: \$16.95.304 pages. ISBN \# 0-88266-769-0. Store Communications, Inc. Schoolhouse Road, Pownal, VT 05261. tel: 802-823-5819.

\section{Published outside of the United States}

Cloet, Audrey and Chris Underhill. 1990. Gardening/s for Everyone. ISBN \# 0-285-64954-X. 197 pages. Horticultural Therapy, Goulds Ground, Vallis Way, Frome, Somerset BA11 3DW. Tel: (0373) 464782.

Hewson, Mitchell L., HTM. 1994. Horticulture as Therapy. ISBN \# 0-9698061-0-8. Greenmor Printing Company Limited, Guelph, Ontario, N1K 1B1. Canada.

Please, Peter. 1990. Able to Garden: A Practical Guide for Disabled and Elderly Gardeners. ISBN \# 073461 373.144 pages. Horticultural Therapy, Goulds Ground, Vallis Way, Frome, Somerset BA11 3DW. Tel: (0373 464782.

Stoneham, Jane and Peter Thoday. 1994. Landscape Design for Elderly \& Disabled People. ISBN\# 1-85341033-0.148 pages. Garden Art Press/Antique Collectors' Club Limited, 5 Church Street, Woodbridge, Suffolk IP12 1DS, U. K.; American Office: Market Street Industrial Park, Wappinger's Falls, NY 12590. 
become a very limited experience for most of America's youth. Many arboreta and botanic gardens, cooperative extension, and other agencies and nonprofit groups are beginning to address this population with its unique needs. Children with special needs, including youth at risk, have been targeted to participate in gardening programs. The children's gardening movement has gained significant momentum recently (see Sidebar C) through such efforts as the National Gardening Association's Grow Lab educational program. Their school gardening grants, consisting of tools, seeds, and garden products valued at an average of $\$ 500$, are available to 300 programs nationwide. The American Horticultural Society has sponsored national conferences targeting school gardening. There are other outstanding national programs for integrating gardening into the elementary school curriculum, including Life Lab (sponsored by the National Science Foundation), and small businesses, such as Gardens for Growing People, dedicated to supplying children's gardening resources. A plant selection guide for children's environments (Moore, 1989) expands the concepts of how plants are used in the landscape. The People-Plant Council has an extensive list of books related to gardening and children, which is available by sending a pre-addressed, stamped envelope to PPC, Office of Consumer Horticulture, 407 Saunders Hall, Virginia Tech, Blacksburg, VA 24061-0327.

Many horticulture industry groups, businesses, and botanic gardens have been involved in supporting children's gardening. In addition, cooperative extension has taken a leadership role in this area in 4-H programs (Whittlesey, Curtis, and Laine, 1991) and through Master Gardener efforts, such as the Virginia Beach 4-H urban gardening project Ready Set Grow (Virginia Cooperative Extension, 1990).

Although the broad concept of children's gardening does not fall under the horticultural therapy umbrella, there are horticultural therapy programs that specifically address children in hospitals and other treatment settings (Kavanagh and Chambers, 1995). In addition, children's gardening programs, from arboreta and botanic gardens, may include horticultural therapy in treatment facilities or accessible gardening for disabled youth (Moore, 1989; Morgan, 1989).

Community gardening and urban greening. Residents in apartments, townhouses, and other sites without access to private garden space benefit from community garden sites. Individuals of all socio-economic statuses have become involved actively in urban greening projects recently. Groups of individuals who are economically and socially disenfranchised are seeking a healthier community and better quality of life through involvement, and ultimately leadership, in community greening activities. Accessing gardening space, tools, and knowledge often necessitates special help for these individuals. Community gardens are particularly important to the elderly, disabled, and disadvantaged individuals in urban areas. Most often, the community garden is developed under the leadership of a group such as the Pennsylvania Horticulture Society (Bonham, 1988, 1991), the Chicago Botanic Garden (Brogden, 1991), or other non- 
profit associations (Carrier, 1985 ) interested in horticulture and using it to improve the quality of life and the appearance of the community. These gardens are located near the people who need them and are run by the people of the community (Dotter, 1994; Keller, 1994; Mattson et al., 1994). The U.S. Dept. of Agriculture Cooperative Extension Service has been influential in establishing community gardens to improve the nutrition of the people gardening, to develop leadership skills among these people, and to help them improve their communities in many other ways ( Patel, 1991). Other organizations, such as the American Community Gardening Association, have resources available for assistance in establishing community gardens.

Healing landscapes. In the design of landscapes for hospitals, nursing homes, and hospices, the presence of plants is considered to be the healing element rather than part of a treatment program in which active participation with plant culture is integral to the therapy. These landscapes may be designed cooperatively with a horticultural therapist to serve the dual purpose of a healing landscape for some clients and a horticultural therapy garden for others. This field is becoming an increasingly recognized element in landscape design. The concept of designing landscapes at hospitals, hospices, and similar sites for their healing qualities rather than merely to cover the grounds is gaining prominence as a result of the work of Ulrich (1984) and Kaplan and Kaplan (1989), which provides much of the theoretical basis for this movement. Francis (1994) and Francis et al. (1994) have drawn together proponents of this concept for an exchange of ideas that has led to two sets of proceedings. The January 1995 issue of Landscape Architecture provides an overview of the current state of the art, as landscape architects continue to explore healing landscapes and therapeutic garden design 'for horticultural therapy (Dannenmaier, 1995; Kavanagh and Musiak, 1993; Leccese, 1995; McCormick,

\section{D) ASSOCIATIONS WITH PROGRAMS FOR SPECIAL POPULATIONS}

American Community Gardening Association, Pennsylvania Horticulture Society, 325 Walnut Street, Philadelphia, PA 19106-2777. Tel: 215-625-8250.

American Horticultural Society, 7931 East Boulevard Drive, Alexandria, VA 22308-1300.

AHS '93 Children's Gardening Symposium Proceedings, "Children, Plants, and Gardens: Educational Opportunities," July 1994 American Horticulturist.

AHS '95 National Youth Gardening Symposium, "Gardens for Youth: Nourishing Mind, Body, and Heart" June 27-30, 1995, in Pasadena, California.

American Horticultural Therapy Association, 362A Christopher Avenue, Gaithersburg, MD 20879. tel: 1-800634-1603.

Friends of American Horticultural Therapy, Inc., 362A Christopher Avenue, Gaithersburg, MD 20879. tel: 1-800634-1603.

Gardeners of America/Men's Garden Clubs of America, Inc., 5560 Merle Hay Road, P.O. Box 241, Johnston, IA 50131. tel: 515-278-0295. 
tial benefits to their clients and wanted to add this tool to their therapeutic activities. Garden clubs traditionally have held garden therapy as one of their major areas of interest. such as Gardening from the Heart, a program of the Gardeners of America, Inc. (formerly the Men's Garden Clubs of America, Inc.). It is their mission to extend and advise current and additional clubs in the formation of a horticulture therapy partnership, extending gardening to youth or adults who are disadvantaged, handicapped, retarded, or mentally ill, and residential elderly, including veterans (Gardeners of America/Men's Garden Clubs of America, Inc., 1990).

One of the most important new contributors to volunteering in horticultural therapy is the cooperative extension Master Gardeners (Flagler, 1992; Patel, 1991 ). The contribution of volunteers is so important that AHTA has a national award for outstanding volunteer efforts.

Human issues in horticulture (HIH). $\mathrm{HIH}$ looks at the influences of plants on people in all aspects of their lives, regardless of special needs of the individuals. Other terms used to refer to this broad concept include socio-horticulture, people-plant interaction, and human dimensions in horticulture. $\mathrm{HIH}$ includes all of the above areas of concern, plus economic and marketing issues; physical and environmental amelioration by plants: food and nutrition; ethnobotany considerations as they apply to horticulture; and the role of horticulture in art, music, drama, and phi- losophy. The broader concepts of $\mathrm{HIH}$ are addressed by ASHS in the socio-horticulture working group and in the International Society for Horticultural Science (ISHS ) in the $\mathrm{HIH}$ working group (under formation). The People-Plant Council was formed in 1990 to encourage research in this area. To accomplish its goals, it has developed many resources available to researchers, students, the industry, and the media. These include books, computerized bibliographies, videotapes, and information on an Internet gopher server (see side bar E). HIH is concerned with the interface between the user of horticultural crops and services and the horticulture industry and professionals (Relf, 1995).

Horticultural therapy. The profession of horticultural therapy is one of the treatment modalities (including art therapy, music therapy, and recreational therapy) that form the adjunctive therapy treatment approach. Horticultural therapy programs are found in psychiatric hospitals, physical rehabilitation facilities, educational centers for individuals with intellectual impairments, and similar treatment facilities. Professional horticultural therapists also work in vocational training programs, sheltered workshops, and prisons. In addition, arboreta and botanic gardens are employing registered horticultural therapists to conduct educational outreach programs for professionals and clients in treatment facilities in their communities. The profession of horticultural therapy is relatively new compared to the other therapeutic and caring professions. Under the leadership of AHTA, there are professional registration and development opportunities that make this a valued and dynamic area. Relatively few books have been published that directly address the development of horticultural therapy programs and the therapeutic activities involved (Daubert and Rothert, 1981). However, because many professionals have gained 15 or more years of service, new books should appear, such as a recent one from Canada (Hewson, 1994). Members of the horticulture industry have become more familiar with the role of a horticulture therapist in providing them with skilled employees through the AHTAprogram, Hor- 
ticulture Hiring Individuals with Disabilities (Davis, 1991 ).Unfortunately, much misunderstanding of the profession still exists, particularly among horticulturists.

\section{Defining horticultural therapy}

To conduct research, teach courses, or design and implement horticultural therapy programs, it is important to understand the basic framework and definition of horticultural therapy, thus sharing a common term for communication. This is made difficult by the fact that the term is used to mean a range of topics. At one end of the range, horticultural therapy is used to mean any gardening activity that helps anyone in any way. Some people like to use the expression, "If it's horticulture, it's therapy." However, this approach implies that, to receive horticultural therapy, all you need to do is plant a seed, and that, to be a horticultural therapist, all you need to do is tell someone to plant a seed. This is far from the truth. Although horticulture is good preventive medicine to help overcome the stress and frustrations of daily life, it is an oversimplification to call any use of horticulture horticultural therapy; just as going for a walk is not the same as physical therapy. The term also is used to talk about community gardening, flower planting and beautification, or vegetables raised by a school child who also happens to have a disability. All of these are oversimplifications and make it difficult to truly understand the nature of horticultural therapy, why it works, and how to implement it.

\section{Who conducts horticultural therapy programs)}

Three groups are involved in implementing horticultural therapy programs:

Professional horticultural therapists are employed to conduct programs that focus exclusively on horticulture as the treatment method. They can receive training at several universities and can be registered with AHTA.

Allied professionals, including occupational therapists, physical therapists, and recreation therapists, use horticulture as one of the many tools or techniques for treating a patient.

Volunteers, including members of garden clubs and cooperative extension Master Gardeners, are knowledgeable about horticulture and wish to help others. Volunteers generally are limited in the amount of time that they contribute to a program (2 to 4 hours per week) and the degree of responsibility that they have (usually assisting a professional). However, there are volunteers who work 20 or more hours a week and take most of the responsibility for the program. There is no set system for this, and it depends on the facility, the program, and the volunteer.

\section{Horticultural therapy as a profession}

In defining horticultural therapy as a profession, it is useful to look at the definitions of allied professions, such as physical therapy and occupational therapy, that use a medical model in their approaches to treatment and receive their salaries based primarily on payments for services from insurance companies, employee health programs, and Medicare/Medicaid. It is to be acknowledged that these professional areas, used as models for the development of horticultural therapy, are well-established fields recognized by the medical community as integral to treatment, having been in existence for almost 100 years. Because horticultural therapy is about 20 years old, it is still very new and not readily acknowledged among the medical community, particularly insurance companies that must pay for professional services. Often, the horticultural therapist at a facility will be hired under the auspices of the occupational therapy department to ensure the payment for services. Horticultural therapists occasionally are employed as activity directors or as recreation therapists when facility budgets do not have the flexibility to include this newer, more specialized treatment area.

Based on material supplied by the American Physical Therapy Association, physical therapy services include identification, prevention, remediation, and rehabilitation of acute or prolonged physical dysfunction or pain, with emphasis on movement dysfunction. Physical therapy staff monitor the extent to which services have met the therapeutic goals relative to initial and all subsequent examinations, as well as the degree to which improvement occurs relative to the identified physical dysfunction or the degree to which pain associated with movement is reduced.

As defined by the American Occupational Therapy Association, registered occupational therapists and certified occupational therapy assistants provide services to people whose lives have been disrupted by physical injury or illness, developmental problems, the aging process, or social or psychological difficulties. Occupational therapy focuses on the active involvement of the patient in specially designed therapeutic tasks and activities to improve function, performance capacity, and the ability to cope with the demands of daily living.

Horticultural therapy, as well as other allied professions, has three main elements: clients, goals, and treatment activities.

Clients are individuals who have been

\author{
Tt is an \\ oversimpl- \\ ification to call \\ any use of \\ horticulture \\ horticultural \\ therapy.
}




\section{$\boldsymbol{B}_{\text {treatment }}^{\text {y establishing }}$} goals and objectives, it is possible to determine the progress that the client is making. diagnosed as having a specific disability or disabilities that can be ameliorated if treated. Clients in horticultural therapy programs are very diverse and represent all categories of disabilities, including, but not limited to, the following:

- Psychiatric. Historically the first recorded area to use treatment through gardening, this remains one of the major areas in which horticultural therapists work in private and public hospitals and out-patient treatment facilities (Diethelm, 1994; Kobren, 1991; Liberman, 1992; Neuberger, 1991; Palamuso, 1985; Schwebel, 1993; Strauss, 1994).

- Geriatric. For the ill elderly, such as those in adult day-care centers, nursing homes, and Alzheimer's programs, horticulture is proving to have a calming and therapeutic effect, resulting in a significant increase in its use recently (Ebel, 1991; Hill and Relf, 1982; Hoover, 1994; Kaplan, 1994; Mattson and Hilbert, 1976; Mooney and Milstein, 1994; Mooney and Nicell, 1992; Roemer, 1994).

- Mental disability. This includes developmental disabilities, mental retardation, and brain injury. This is one of the principle areas of involvement for horticultural therapists. With programs in public and private schools, vocational rehabilitation centers, sheltered workshops, and residential facilities, much of the work is directed toward employment of the clients (Airhart et al., 1987; Cecchettini and Goldman, 1994; DeHart-Bennett and Relf, 1990; Dobbs and Relf, 1990; Schleien et al., 1991).

- Physical disability. Patients with strokes, paralyzing injuries, and many similar diagnoses are being treated in horticultural therapy programs in many locations around the United States (Bales, 1995).

- Sensory impairment. Vocational and recreational programs for visually and hearing impaired persons use horticultural activities as part of their rehabilitation. However, gardens for the blind are recognized as stereotypical and undesirable. Emphasis is placed on gaining skills for daily living (Craig, 1994; Perkins School for the Blind, 1993).

- Substance abuse. Individuals who abuse alcohol, drugs, and even food have responded to horticultural therapy at certain stages in their treatment (Cornille et al., 1987; Hewson, 1994).

- Social deviation. Adults and children who are maladapted to social norms and commit crimes that place them in prisons or detention centers have benefitted from horticultural therapy (Flagler, 1993; McCombe-Spafford, 1994; McGinnis, 1989; Pruyne, 1994; Rice and Remy, 1994; Whittlesey, 1994).

Defined treatment goals are diverse and depend on the diagnosis of the individual and the treatment facility where the program is being conducted. There are two types of treatment goals that must be reconciled: facility treatment goal and client treatment goal. Depending on various factors, including the stage of the disability being addressed and the prognosis, an individual could be in any one of several different treatment facilities with different goals. These facility treatment goals include, but are not limited to, vocational rehabilitation and placement, rehabilitation and return to the community at reduced functioning level, maintenance of functioning level without institutionalization, sheltered or supported employment, and delayed progress of disability. Zandstra ( 1987, 1988 ) described individualized treatment goals as part of the total treatment plan that is developed cooperatively with the client and addressed specific needs of that individual. The individualized treatment goal is achieved through a series of treatment objectives that are clearly attainable and measurable. Each treatment objective is written to include the desired behavior or response, the circumstances under which that behavior will occur, and the minimum acceptable performance of the behavior.

By establishing treatment goals and objectives, it is possible to determine the progress that the client is making and determine when the patient has derived all the benefit anticipated from a treatment program. This type of documentation increasingly is being required as justification for payment of treatment procedures by insurance companies or government reimbursement agencies.

In reality, due to limited staff, it is impossible to individualize the treatment goals and objectives to the desirable degree discussed. Standardized client treatment goals are used to apply to all the patients in the program, with individual progress records being kept.

In addition to facility treatment goals and individualized treatment goals, many horticultural therapy programs have unwritten goals they are expected to achieve. These generally have less to do with client treatment than with funding or prestige; for example, the horticultural therapy program is often the most aesthetically pleasing portion of a facility and, therefore, is expected to host all visitors despite any impact it may have on the treatment program. Products or services that are a by-product of the treatment of a client (i.e., pot plants, vegetables, and grounds maintenance services) have economic value 
and are expected to contribute significantly to the budget of the program. These goals must be integrated into the overall program goals if success is to be achieved.

Treatment activities must focus on the cultivation of living plants if the program is truly to be horticultural therapy. Occasional activities may include arts arid crafts. field trips, and reading, but, ultimately, a major therapeutic aspect of horticultural therapy is the benefit to be derived from nurturing plants; therefore, living plants are essential. Beyond that, the type of horticultural activity should be adjusted to meet the abilities and needs of the client. Specific considerations include the following:

- The activity should be the smallest, simplest one available to achieve the desired goal, thus benefiting the most clientele.

The therapeutic aspect of the activity is the process itself, not the finished product.

- Clients who are not participating actively in a specific project, but passively watching (even from their windows ), will derive some psychological and physiological benefit from the plant and should be encouraged to continue their observations until they are ready to participate.

Examples of horticulture treatment ac tivities include producing greenhouse crops, learning to make terrariums and bonsai, harvesting flowers, making dried flower arrangements, pulling weed, and transplanting trees. Because of the diverse clientele, any horticultural activity could potentially be part of a successful horticultural therapy program, if appropriately modified to meet the abilities and needs of the client. However, high among the horticultural activities that have long been seen as very motivational are potting plants, plant propagation, and flower arranging [Relf (Hefley), 1973; Relf, 1978].

Horticultural therapy is part of an overall treatment plan, and the people conducting horticultural therapy programs work closely with all other members of the treatment facility to reach the goals. For other professionals (such as occupational, physical, or recreational therapists) using horticulture as one of their treatment activitiies, the goals of horticulture will be integrated into the individualized treatment goals of the patient in a similar manner.

Because the professionals may rely on volunteers, it is essential that professionals in horticultural therapy develop the skills to work with volunteers. For volunteers working with patients in horticultural therapy, the goals are much more generalized, and they are not requested to maintain records in the same way as professionals. The generalized goals of volunteers in horticultural therapy include helping clients learn to have fun and laugh again, helping clients understand that they are still valuable and people from their community still care about them, helping clients improve physically by getting the exercise of gardening, or helping elderly persons improve mentally by talking about childhood memories of gardening to someone who truly wants to listen.

\section{Literature Cited}

Adil, J.R. 1994. Accessible gardening for people with physical disabilities: A guide to methods, tools, and plants. Woodbine House, Bethesda, Md.

Airhart, D.L., T. Willis, and P. Westrick 1987. Horticultural training for adolescent special education students. J. Therapeutic Hort. 2: 17-22.

Bales, S.F. 1995. The kitchen garden: Raised beds and electric chairs. Horticulture 73(1):34-39.

Beems, J. 1985. Personalized tools and techniques. In: Reaching out to special populations. Spec. ed. Community greening review. Amer. Community Gardening Assn.

Bonham, B. 1988. Green Towne Country: A development guide. Pennsylvania Hort. Soc., Philadelphia.

Bonbam, B. 1991. Philadelphia Green's Greene Towne Country model as an agent for community development: findings of case studies. In: D. Relf (cd.) The role of horticulture in human well-being and social development: A national symposium (proceedings). Timber Press, Portland, Ore.

Brogden, S.B. 1991. Chicago Botanic Garden examines its social and economic role in the city of Chicago and Cook County. In: D. Relf (cd.) The role of horticulture in human well-being and social development: A national symposium (proceedings). Timber Press, Portland, Ore.

Bubel, N. 1990. A therapy garden. Country J. (September/October):74-76.

Burlingame, A. 1974. Hoe for health. Guidelines for successful horticultural therapy programs. Michigan Garden Consultants, Birmingham

Carrier, J. 1985. Horticultural therapy and community gardening. In: Reaching out to special populations. Spec. ed. Community greening review. Amer. Community Gardening Assn.

Cecchettini, C.L. and B. G. Goldman. 1994. A case study of horticultural therapy for adults with developmental disabilities: Methodological issues. In: M. Francis, P. Lindsey, and J.S. Rice (eds.). The healing dimensions of people-plant relations. Center for Design Res., Univ. of California, Davis.

Cloet, A. and C. Underhill. 1990. Gardening is for everyone. Horticultural Therapy, Frome, U.K.

Cornille, T.A., G.E. Rohrer, S. G. Phillips, and J. G. Mosier. 1987. Horticultural therapy in substance abuse treatment. J. Therapeutic Hort. 2:3-8.

\section{$\mathcal{B}_{\text {diverse }}^{\text {ecause of the }}$ clientele, any horticultural activity could potentially be part of a successful horticultural} therapy program 
Craig, K.A. 1994. Teaching gardening to the blind as therapy. In: M. Francis, P. Lindsey, and J.S. Rice (eds.). The healing dimensions of peopleplant relations. Center for Design Res., Univ. of California, Davis.

Dannenmaier, M. 1995. Healing gardens. Landscape Architecture 85(1):56-58.

Daubert, J.R. and E. Rothert. 1981. Horticultural therapy series. Horticultural Therapy Services, Chicago Hort. Soc., Glencoe, Ill.

Davis, S.H. 1991. American Horticultural Therapy Association-Horticultural hiring the disabled (HHD) project: Final performance for the period of October 1,1992, through September 30,1991, for projects-with-industry grant \#G0082c0017. Amer. Hort. Therapy Awn., Gaithersburg, Md.

DeHart-Bennett M.E. and P.D. Relf 1990. Hort cultural careers for persons with mental retardation. J. Vocational Spec. Needs Educ. 12(3):11-15.

Diethelm, K. 1994. Horticultural therapy in a state hospital setting. In: J. Flagler and R.P. Poincelot (eds.). People-plant relationships: Setting research priorities, A national symposium (proceedings). Hayworth Press, Binghamton, N.Y.

Dobbs, G.S. and P.D. Relf 1991. Enclave employment of disabled individuals in a university grounds maintenance department: A case study. J. Therapeutic Hort. 6:38-49.

Dotter, J. 1994. Cultivating people-plant relationships in the community and cultural heritage gardens of San Jose, California, 1977-1992. In: J. Flagler and R.P. Poincelot (eds.). People-plant relationships: Setting research priorities, A national symposium (proceedings). Hayworth Press, Binghamton, N.Y.

Ebel, S. 1991. Designing stage-specific horticultural therapy interventions for patient's with Alzheimer's disease. J. Therapeutic Hort. 6(1):3-9.

Flagler, J. 1992. Master Gardeners and horticultural therapy. HortTechnology 2:249-250.

Flagler, J. 1993. Correctional youth and the green industry. J. Therapeutic Hort. 7(1) :49-55.

Francis, M. and R. T. Hester, Jr. (eds.). 1994. The meaning of gardens. MIT Press, Cambridge, Mass.

Francis, M., P. Lindsey, and J.S. Rice. 1994. The healing dimensions of people-plant relations: A research symposium. Center for Design Res. Univ. of California, Davis.

Fuller, B. 1993. Marketing to people with disabilities. Amer. Nurseryman 178(8):46-47, 49.

Gardeners of America/Men's Garden Clubs of America. 1990. Gardening from the heart program: Horticulture therapy (pamphlet). Gardeners of Amer./Men's Garden Clubs of Amer., Johnston, Iowa.

Hewson, M.L. 1994. Horticulture as therapy. Greenmor Printing Co., Guelph, Ontario, Canada.

Hill, C.O. and P.D. Relf 1982. Gardening as an outdoor activity in geriatric institutions. Activities,
Adaptation \& Aging 3(1):47-54.

Hoover, R.C. 1994. Healing gardens and Alzheimer's disease. In: M. Francis, P. Lindsey, and J. Stone Rice (eds.). The healing dimensions of people-plant relations. Center for Design Res., Univ. of California; Davis.

Kaplan, M. 1994. Use of sensory stimulation with Alzheimer patients in a garden setting. In: J. Flagler and R.P. Poincelot (eds.). People-plant relationships: Setting research priorities, A national symposium (proceedings). Hayworth Press, Binghamton, N.Y.

Kaplan, R. and S. Kaplan. 1989. The experience of nature: A psychological perspective. Cambridge Univ. Press, New York.

Kavanagh, J.S. and N. Chaznbers. 1995. The children's playground project at the Howard A. Rusk Institute for Rehabilitation Medicine. Child Health Design 9:19.

Kavanagh, J.S. and T.A. Musiak. 1993. Selecting design services for therapeutic landscapes. J. Therapeutic Hort. 7(1):19-22.

Keller, T. 1994. Gardening changes a community. In: J. Flagler and R.P, Poincelot (eds.). Peopleplant relationships: Setting research priorities, A national symposium (proceedings ). Hayworth Press, Binghamton, N.Y.

Kobren, G. 1991. Deep-rooted therapy: Gardening blossoms as a tool of healing. The Baltimore Sun, 1 Oct.

Leccese, M. 1995. Nature meets nurture. Landscape Architecture 85( 1 ):68-71.

Liberman, R.P. 1992. Effective psychiatric rehabilitation. New Directions for Mental Health Serv., Jossey-Bass.

Mattson, R. and R. T. Hilbert. 1976. Psychological, social, physical and educational effects of horticultural therapy for geriatrics. HortScience 11:328.

Mattson, R.,J. Merkle, B. Hassan, and T. Waliczek. 1994. The benefits of community gardening. Community greening review. Amer. Community Gardening Assn.

McCombe-Spafford, A. 1994. Horticulture and the captive audience: Gardening's effect on prison inmates. In: M. Francis, P. Lindsey, and J. Stone Rice (eds.). The healing dimensions of peopleplant relations. Center for Design Res., Univ. of California, Davis.

McCormick, K. 1995. Realm of the senses. Landscape Architecture 85(1):61-63.

McGinnis, M. 1989. Gardening as therapy for children with behavioral disorders. J. Child Adolescent Psychiatric and Mental Health Nursing 2(3):87-91.

Mooney, P.F. and S.L. Milstein. 1994.Assessing the benefits of a therapeutic horticulture program for seniors in intermediate care. In: M. Francis, P. Lindsey, and J. Stone Rice (eds.). The healing dimensions of people-plant relations. Center for Design Res., Univ. of California, Davis. 
Mooney, P. and P.L. Nicell. 1992. The importance of exterior environment for Alzheimer's residents: Effective care and risk management. Health Care Forum 5(2):23-29.

Moore, B. 1989. Growing with gardening: A twelvemonth guide for therapy, recreation, and education. Univ. of North Carolina Press, Chapel Hill.

Morgan, B. 1989. Growing together: Activities to use in your horticulture and horticulture therapy programs for children. Pittsburgh Civic Garden Center, Pittsburgh.

Neace, P. 1985. Making it easy. In: Reaching out to special populations. Spec. ed. Community greening review. Amer. Community Gardening Assn.

Neuberger, K.R. 1991. Horticultural therapy in a psychiatric hospital: picking the fruit. In: D. Relf (cd. ) The role of horticulture in human well-being and social development: A national symposium (proceedings). Timber Press, Portland, Ore.

Palamuso, J. 1985. Horticultural therapy in a historic setting. Amer. Hort. (August):4-6.

Patel, I. C. 1991. Gardening's socioeconomic impacts: Community gardening in an urban setting. J. Extension 29(W):7-8.

Perkins School for the Blind. 1993. Horticulture program. Perkins School for the Blind, Watertown, Mass.

Please, P. 1990. Able to garden: A practical guide for disabled and elderly gardeners. Horticultural Therapy, Frome, Somerset, U.K.

Pruyne, R. 1994. Gardening for the health of it. Penn State Agr. (Fall/Winter) :34-40.

Relf (Hefley), P.D. 1973. Horticulture-A therapeutic tool. J. Rehab. 39(1):27-29.

Relf P.D. 1978. Horticulture as a recreational activity. Amer. Health Care Assn. J. 4(5 ):68-71.

Relf P.D. 1994. The accessible garden. Flower and Garden Msg. 37(6):40,42.

Relf P.D. 1995. The significance of horticulturehuman interaction to the horticulture industry and researchers, p. 89-1 00. In: E. Matsuo and P.D. Relf (eds.). Horticulture in human life, culture, and environment, A national symposium (proceedings). Acts Hort. IHC Proc. 391.

Rice, J.S. and L.L. Remy. 1994. Cultivating self development in urban jail inmates. In: M. Francis, P. Lindsey, and J.S. Rice (eds.). The healing dimensions of people-plant relations. Center for Design Res., Univ. of California, Davis.

Roemer, G. 1994. Hope and healing through horticulture. Catalyst (September): 16-17.

Rothert, G. 1994. The enabling garden. Taylor Publ. Co., Dallas.
Saunders, F. 1994. A marketing niche: Consider the elderly. Austral. Hort. (October): 57, 60.

Schleien, S., J. Rynders, T. Mustonen, L. Heyne, and S. Kaase. 1991. Teaching horticultural skills to adults with autism: A replicated case study., J. Therapeutic Hort. 6(1):21-37.

Schwebel, A.I. 1993. Psychological principles applied in horticultural therapy. J. Therapeutic Hort. $7(1): 3-12$.

Stevens, M. 1995a. Life in fast-forward reverse. Landscape Architecture 85(1):71-79.

Stevens, M. 1995b. The promotion of wellness. Landscape Architecture 85(1):64-67.

Stoneham, J. and P. Thoday. 1994. Landscape design for elderly and disabled people. Garden Art Press/Antique Collectors' Club, Suffolk, U.K.

Strauss, M. 1994. Measuring the quality of treatment in horticultural therapy groups. In: J. Flagler and R. P. Poincelot (eds.). People-plant relationships: Setting research priorities, A national symposium (proceedings). Hayworth Press, Binghamton, N.Y.

Sutro, D. 1995. Mending wall. Landscape Architecture 85(1):72-75.

Ulvich, R.S. 1984. View through a window may influence recovery from surgery. Science 224:420421.

Virginia Cooperative Extension. 1990. Ready set grow. Virginia Beach 4-H Urban Gardening Project, Virginia Coop. Ext., Virginia Beach.

Wanzer, S.B. 1995. Restorative landscapes. Landscape Architecture 85( 1): 128

Watson, D.P. and A.W. Burlingame. 1960. Therapy through horticulture. MacMillan, New York.

Whittlesey, L.A. 1994. Master Gardener programFederal prison camp-Bryan, Texas. In: J. Flagler and R.P. Poincelot ( eds. ). People-plant relationships: Setting research priorities, A national symposium (proceedings). Hayworth Press, Binghamton, N.Y.

Whittlesey, L, M.M. Curtis, and G. W. Laine. 1991. Plant pals: 4-H horticulture guide for clover kids. Texas Agr. Ext., Texas A\&M Univ., College Station.

Yeomans, K. 1992. The able gardener. Storey Communications, Pownal, Vermont.

Zandstra, P.J. 1987. Evaluating the effectiveness of your horticultural therapy program. J. Therapeutic Hort.2:23-28.

Zandstva, P.J. 1988. A systematic approach to horticultural therapy. J. Therapeutic Hort. 3:15-24. 